https://helda.helsinki.fi

\title{
Semanttisia huomioita lauseenvastikkeista
}

\section{Hakulinen, Auli}

1974

Hakulinen , A 1974 , ' Semanttisia huomioita lauseenvastikkeista ', Sananjalka (Turku), Vuosikerta. 15 , Sivut 38-68.

http://hdl.handle.net/10138/236509

cc_by

publishedVersion

Downloaded from Helda, University of Helsinki institutional repository.

This is an electronic reprint of the original article.

This reprint may differ from the original in pagination and typographic detail.

Please cite the original version. 
2. Max believed Melvin to be immortal. 'Max luuli jne. proved Melvinin olevan kuolematon.

found

Lauseessa (1) oleva Melvin on nostettu komplementtilauseen subjektin paikalta matriisilauseen subjektiksi. Sen lähtömuoto on (3).

3. Seems $\left[{ }_{N P}[\right.$ Melvin to be immortal $\left.]\right]$

Tämän kirjoituksen tarkoituksena on tuoda muutamia semantti-

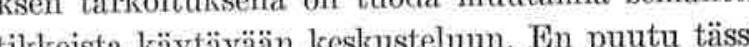

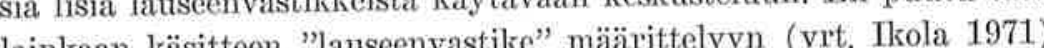
lainkaan kesterisnivaan kasittelen in "is meksi väljästi sopii lauseenvastike. 'Tarkastch kohtcena ovat lăhinnä seuraavat kolme seikkala. 1. Nostosaăntó on "Nkksity" englanmi kielen kuvausta varten. Missä määrin se on käyttökelpoinen suomen kieliopissa? 2. Jos pysytellään suurin piirtein generativisen semantiikan tutkimusperinteessä, joudutaan lâhtemaăn sellaisesta näkemyksestä, että semanttisen eron olisi ilmettava puukuvioiden erona Modaalien tapauksessa näin ei näyttäisi kovinkaan luontevasti käyvän. Esitän ongelman, mutta tuskin pystyn sită ratkaisemaan. 3. Vhälle huomiolle ovat jääneet sellaiset upotetut lauseet, joissa o kopula. Kiinnostavaa olisi selvittää, mikä niiden historia on. Tyydyn tässä vain viittaamaan historiassa odottaviin kysymyksiin.

1. Taustaa

Teolsessaan "On Raising" Postal esittää kymmenittäin todisteit sen puolesta, ettã englannin kieliopissa on oletettava toin RAISING 'NOSTO', joka nostaa komplementtilauseen subjekt' matriisilauseeseen joko subjektiksi tai objelktiksi. Nostettavana on siis vain subjekti, mutta se voi päätyä jommaksikummaksi kahdesta lauseenjäsenestä. Seuraavat englamnin esimerkkilauseet selittyvàt tämän NOSTOsäännön avulla.

1. Melvin seems to be immortal. 'Melvin näyttää olevan kuolematon.'
Tällaisia yksipaikkaisia verbejä, kuten scem 'näyttää', jotka saavat pelkästään lausesubjektin lähtörakenteessaan, Postal nimittää Averbeiksi (A-element raising triggers, subjektin noston aikaansaavia verbejä). Näitä ovat hänen mukaansa esim. pinta-adjektiivit apt, bound ja likely sekä sellaiset verbit kuin appear, begin, happen, remain, tend ynnä modaaliverbit. Yhteensä Postal mainitsee n. 70 A-verbiä, joten tämä jokseenkin yleisesti muidenkin hyväksymä sääntö tuntuu keskeiseltä englannin kieliopissa.

Lauseessa (2) oleva NP Melvin taas on sirrtynyt alemman lauseen subjektin paikalta ylemmän lauseen objelztiksi. Verbejä, jotka aiheuttavat tämän siirtymän, on hänen mukaansa kolme hieman eri tavoin käyttäytyvää ryhmää, B-verbit kuten believe, find, show. W-verbit luten expect, intend like, prefer ja want; N-verbit prevent, W-verbit stop stop, hech, dis con lee yhtensa ky a tamă analyysi on elelleon lihstanalaine, ja lahes jolasta Postalin argunentia vast taehdotuksen mukaan näissä lauseissa ei tapahlu mitaan nostoa, infinittistyy. Puattumatta enempaa englannin kielen ylsityiskohtiin voi todeta, että mikäli nostetuksi epäilty konstituentti käyttäytyy itsenäisesti muuhun konstituenttilauseeseen nähden, yksinkertaisin selitys on, että se on nostettu ylemmän lausseen jäseneksi.

Postal ei tyydy vain olettamaan NOSTOsäännön tarpeellisuutta englannin kielessă, vaan hän ehdottaa, että sääntö kuuluu universaaliin kielioppiin. Muutaman ranskasta ja japanista saamansa esimerkin nojalla Postal esittää, että kielet pyrkivät noudattamaan lauseivaan alempi lause menettăa "muusta syysta lausemaisuutensa ja 
den liitännässä "funktionaalista seuraamusperiaatetta" sekä sen mukaista yleissääntöä (4):

4. Siirrä komplementin subjekti.

Jos tämä yleistys on pätevä, meillä on näin ollen kaksi yleispätevää säänöä: EKVI (=identtisen NP:n poistosääntö) ja NOSTO, joita soveltamalla lausseyhdisteestä saadaan kiinteä kokonaisuus ja upotettu lause menettää lausemaisuuttaan:

"Clauses which cyclically lose their subject NP through the pres like EQUI or RAISING are assigned to a derivative category of clauses called quasi-clauses. In general, such clauses impose much less of a barrier to various syntactic processes than full clauses do." (käsik. s. 161)

Suomen kielen kannalta tämä hypoteesi herättääa seuraavat kysynykset. 1. Millaisena NOSTO esiintyy tai on tarpeellinen suomen kieliopissa? 2. Onko ehkä muita keinoja kuin identtisen NP:n poisto ja NOSTO, joiden avulla päästään eroon alemman lauseen subjektista ja näin ollen alennetaan ko. lause kvasilauseeksi? 3. Mikà on taustana oleva rajoitus? Voidaan ajatella, että periaate "Ei kahta nominativisssa olevaa NP:tä suoraan saman S:n dominoimina" vai kuttaisi siten, että alempi subjekti on muokattava tavalla tai toisella. Chomskyn ehdotus on, että rajoitus koskisi finiittiverbejä: ei kaht finiittiverbië saman S.n dominoimana. 4. Onko lausemaisuutta vain Walta

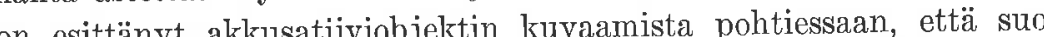
n estüröt lausemaisuutensa" myöhem-

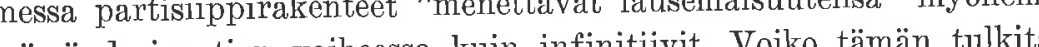
mässa derivaation vaiheessa kuin infintilivit.

myös se, onko NP-mäisyyttäkin oletettava useit Jat lauseet ja infinitivivit räyttäytyvät siinä määrin toisin kuin gerundirakenteet ja "tavalliset" NP:t, ettei niiden kuvaukseen voi katsoa Kuuluvan rakenteen ( ${ }_{\mathbb{N}} \mathrm{S}$ ) Mikäli notaatio olisi lauseopissa yhta johdonmukaista kuin fonologiassa, meidïn olisi periaatteessa kyettavà osoittamaan eri komplementuritomtion jinteysasteet notaation eroina. T'oistaiselssi taman on viela melko hapa.
2.1. Subjektin kato

Ennen kuin siirryn käsittelemään nostoa, tarkastelen lyhyesti toista subjektille mahdollista kohtaloa, sen katoa. - Muun kuin chomskylaisen "standarditeorian" kannattajat katsovat infiniittisen muodon syntyvän siten, että lauseesta häviää subjelkti, jonka jälkeen sen predikaattiverbi ei voi enää mukautua, vaan infiniittistyy (ks. esim. Kiparsky ja Kiparsky 1970). Tämä selitys vaatinee tarkistusta jos otetan huomioon toisaglta lauseet joista subjekti katoga

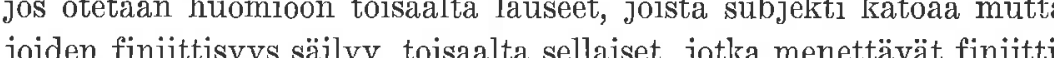
joiden finittisyys sailyy, toisaalta sellaiset, jotka menettavaăt finiitt syytensá sitca holfoutta ettà nilsta ei poisteta tai nosteta subjektia. Kumpaakin tyyppia olevia lauseita on helppo loy taa suomesta: edellisista kelpaavat esito henkilo (6), joissa tosin voi olettaa olevan subjektin vielä kriittisessä johtamisen vaiheessa. Jälkimmäisestä sopisivat tämän jälkeen esimerkeiksi passiivinen ( 7 ) seka elssistentiaalinen (8) komplementtilause, joista ei ole poistettu subjektia mutta jotka silti ovat menettäneet finiittisyytensä, kun ne on muutettu partisiippirakenteiksi.

5. Talvella uidaan avannossa.

6. Näin kovalla tuulella kaatuu.

7. Talossa tuntuu valvottavan.

. Pekka sanoo pihalla juoksevan poikia.

Näistä faktoista seuraa, että ei-finiittisen muodon syntymistä ei voida ainakaan suomessa esittää pelkästään subjelktin häviämisen tulokseksi. Kun näin on, meiltä on jo osalssi kadonnut motivaatio väittää esim. Wiikin tavoin, että lauseessa Kunlin suden ulvovan täytyy olettaa NP:n susi nostetun genetiivimuotoiseksi datiiviksi matriisilauseeseen, jos kerran partisiippirakenteen muodostamiseen tätä nostosääntö̈̈̈ ei tarvita. Palaan tähän kysymylsseen tuonnempana tarkasteltuani ensin vedenpitäviä tapauksia, ts. sellaisia, joissa näyttarkasteltuani ensin vedenpitäviä, tapauksia, ts. sellaisia, joissa näyt-
tää tarvittavan jompaakumpaa mainituista kahdesta säännöstä tâä tarvittavan jompaakumpaa mainituista kahdesta säännöstä oikean pintarakenteen saavuttamiseksi. Seuraavat lauseet havain-
nollistakoot sen, että EKVI on sopiva universaalitarjokas suomenki nollistakoot sen, että EKVI o
kannalta. Sääntö sanoo näin:

\footnotetext{
${ }^{2}$ Hakulinen ja Karttunen (1973)
} 
9. Poista alemmasta lauseesta ylemmän lauseen subjektin kanssa Pusta altsinen (koreferentiaalinen) subjekti.

Tätä sääntöä on sovellettu esim. seuraaviin tyyppeihin.

10. Pojat haluavat laulaa.

11. Poika haluaa syödä omenan.

12. * Pihalla haluaa juosta poikia.

13. Tällä halutaan syödä omena $\neq$

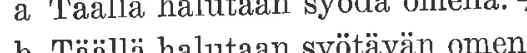

Liisa haluaa auton.

14. Liisa haluaa auton.

15. Suomessa haluaa joutua saunaan.
16. Liisa haluaa $($ tulla $)$ rikkaalssi.

16. Liisa haluaa $\left\{\begin{array}{l}\text { (tulla) rik } \\ \text { olla rikas. }\end{array}\right.$

kerbi haluta vaatii henkil subjektin, jollaista eksistentiaalilauseessa EKVI-säännön soveltamisvaiheessa ei enää ole. Tämä edellyttää, ettã eksistentiaalilauseisiin on jo tätä ennen sovellettu subjektinalennusääntöä, jolla subjekt 列 äännolle ja muille objektisäännöille. ${ }^{3}$ Lauseet (13 a) ja (13 b) ciät of että EKVIn ehdoksi ei riit iden "samuus". Niivain natrielteiset, jotta EKVI-sääntö sovelden on oltava njo tuisi. Vain las (13i) on "heikloa", passivin päätteeksi päölauseessa $(13 \mathrm{~b})$ on kylla kaksi he eikaviitteiset

tyväa subjektia, mutta ne eivat ole

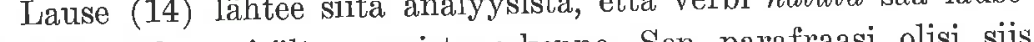
objektin, johon sisältyy omistusrakenne. Sen parafraasi olisi siis (14') s Toinen argumentti sen puolesta, että subjekti-NP alennetaan eksistentiaalilausinenhan voi viitata vain lauseen subjekti-NP:hen.

12 a * Pihallaan voi juosta poikia.

Amerikkalaiset haluavat päästä kuuhun $\neq$
14'. Liisa haluaa, että Liisalla on auto.

Lause (15) on geneerinen. Sen subjektina on kadonnut henkilö, jolka aiheuttaa EKVIn, vaikka ei itse pystykään saamaan fonologista ilmiasua pinnassa. Poistuva NP on aina muuten upotetun lauseen subjektina, mutta kontrolloiva NP sen sijaan voi olla missä pintasijassa tahansa. Tätä havainnollistakoot seuraavat Ikolan (1971) mainitsemat lauseet.

17. a Minä haluan lähteä.

b Minua haluttaisi lähteä matkalle.

c Minulla on tapana syödä hyvää ruoka

d Minusta tuntui kolkolta jättää kotini.

Varmasti voidaan esittää argumentteja sen puolesta, että näissä kaikissa EKVIn kontrolloijana on syvä subjelkti. Tämän todistamiseksi on osoitettava, että sellaisten lauseiden kuin (18 a) ja (18 b) syntaktiset erot johtuvat EKVIä seuraavista säännöistä.

18. a Minä pellkään mennä yksin metsään.

b Minua pelottaa mennä yksin metsään.

2.2. Nostoko?

On ryhmä verbejä, joiden asema EKVIn ja NOSTOn suhteen on kyseenalaisempi. Vertaa toisiinsa seuraavien esimerkkien a- ja blauseita.

19. a Matti pakotti Pekkaa maalaamaan aidan. odotti

b Matti odotti Pekan maalaavan aidan.

20. a I persuaded John to see the doctor.

b I expected John to see the doctor.

21. a Jag förbjöd pojken att komma till mig.

b Jag såg pojken komma till mig.

Kustakin kielestä on löydettävissä argumentteja sen puolesta, että a- ja b-lauseita ei voi analysoida samalla tapaa ja etenkin että a-lauseita ei voi käsittää siten, että niiden objekti-NP olisi lähtöisin upotetun lauseen subjektin paikalta. Argumentiksi sen puolesta, etta 
nïn on sopii esimerkki, jonka upotetussa lauseessa ei ole leksikaalista subjektia ; a-lauseista tulee epäkieliopillisia.

22. * Matti odotti pyryttämään / olemaan kevät

23 * I persuaded there to be an investigation.

24. * Jag förbjöd det att regn

Huomattavaa on, että "kadonnut henkilö" käyttäytyy leksikaalisen subjektin tavoin; näin ollen lause (25) on kieliopillinen ja luonteeltaan siis geneerinen:

25. Jeesus kehottaa tulemaan lasten kaltaisiksi.

Näistä faktoista on pyritty päättelemään se intuitionmukainen seikka, että a-lauseiden lähtömuoto olisi suunnilleen seuraavanlainen.

26. Matti pakotti Pekkaa [Pekka maalaa aidan]

Matriisilauseen objektin kanssa samaviitteinen alemman lauseen subjekti poistetaan EKVI-säännöllä, ja lause infiniittistyy. Tällaisubjekti poistetaan EKVi-saannôta suomessa seuraavat ryhmät.

\begin{tabular}{lll|l}
\multicolumn{2}{l|}{ sen analyysin } & saavia verbeja ovat suomessa seuraat & \\
ahdistelee & kannustaa & neuvoo & estää \\
komentaa & kehottaa & ohjaa & kieltää \\
käskee & kutsuu & opastaa & pelottaa \\
painostaa & lahjoo & opettaa & pidättäää \\
pakottaa & maanittelee & & varottaa \\
taivuttaa & odottaa & + III inf:n & + III inf:n \\
vaatii & pyytää & illatiivi & elatiivi \\
& ruikuttaa & &
\end{tabular}

Mainitussa NOSTOa koskevassa tutkimuksessaan Postal on esittäyt ajatnksen, että ainakin osa näistä verbeistä putoaa englannis katering B (kuten expect) ja N (negative causation kuten

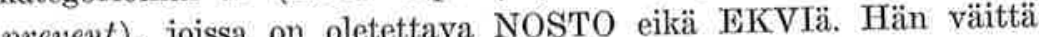
prevent), jois $: n$ lettaminen matriisilauseen lähtömuotoon etta objekt aina ole semanttisesti pent välttämätẗ̈ kohdistu objekti-NP:n verbin ilmaise tointa vatimuksesta tms. epäsuorast
27. Kuningas vaatii alamaisia kunnioittamaan valtaistuinta.

28. Kyltti käskee varomaan heikkoja jäitä.

mästä kes̈̈lomalle.

Postal ehdottaakin tällaisiin tapauksiin seuraavaa syvärakennetta.

30. CAUSE I [AGREE Bob [EXAMINE Bob Gladys]] $\Rightarrow$ I persuaded Bob to examine Gladys.

Suomessa voitaisiin vastaavasti esittää, että kaikki edellä luetellut verbit koostuisivat semanttisesti kausatiivista + verbistä SUOSTUA, jonka subjektina pakottamisen, vaatimisen tms. kohde on: 31. AIH minä [SUOSTU Pekka [MAALAA Pelkka aita]]

Näin ollen verbien yhteinen, ydinmerkitys olisi $X$ suostuttaa $Y: n$ tekemään jotakin, negatiivisissa tapauksissa taas $X$ suostuttaa $Y: n$ NEG tekemään jotakin. Tämän jälkeen tarvitaan alimmalla kierroksella (eycle) EKVI, joka poistaa NP:n Pekka; seuraavalla kierroksella sovelletaan predikaatinnostoa, joka sulauttaa kausatiivisen abstraktiverbin ja suostumisverbin yhteen. Postalin mulkaan nyt seuraisi NOSTO-sääntö, mutta sille edellytyksenä oleva lauseraja on jo käsittääkseni tuhoutunut predikaatinnoston yhteydessä. - Myönnettävä kyllä on, että lauseet (27)-(29) voidaan tulkita siten, että vaatiminen tms. ei suoraan kohdistu alemman lauseen subjektina olevaan henkilöön. Eri asia on kuitenkin, millä mekanismilla tämä tulkintaero saadaan luontevasti esiin.

2.3. Varma sä̈ntö: subjektista subjektiksi

Ei suinkaan ole niin, että mikä tahansa verbi, joka voi saada lausesubjektin, sallisi tuosta lauseesta nostettavan subjekti-NP:n pintasubjektikseen. Esimerkilssi seuraavat verbit voivat kyllä saada lausesubjektin, mutta ne eivät salli ko. nostosäännön soveltamista: ihmetyltää, johtuu, käy ilmi, merkitsee, riïtä̈ä, seuraa; on ilmeis$t \ddot{a}$ / varmaa / yhdentekevää. Tälle rajoitukselle on yritetty etsiä semanttista syytä, ja yksi selitys on että mainitut verbit ovat faktiivisia (ks. Kiparsky ja Kiparsky). Tämä tarkoittaa sitä, että niiden komplementtilauseet muodostavat "saarekkeen" (island) josta voi nosta yhtä konstituenttia pois, Seuravien esimerkkien b-lauseet ovat tästä syystä epäkieliopillisia. 
Thmetyttää, että Pekka rakastaa Liịsaa. b * Pekka ihmetyttää rakastaa Liisaa.

33. a Tästä seuraa, että asia viivästyy.

b * Tästä asia seuraa viivästyvän.

Kun selvitellään, päteekö NOSTO suomeen, ei siis edellytetäkään, Ke. selvitencel täyttävä verbi aiheutettä jokainen tietyt strulktualset taisi tuon salsnon soveltuming Koverbien alaryhmä. s veltamalla NOSTOa.

34. Pojat allavat laulaa.

35. Pihalla näyttää juoksevan poikia

36. Täällä satutaan syömään omena.

37. Liisalla taitaa olla auto.

8.

Nämä esimerkit antavat aihetta seuraaviin huomautuksiin. EnsinNama chi nâkin kanattä alkaa. Toinen niistä on toisin sanoen on olemassa ka henkilösubjektin ja lauseobjektin. ryhtya-verbin synony Tamân alkaa-verbin kanssa esingä heessa enää subjektia:

39. a * Pihalla ryhtyy juoksemaan poikia.

b * Ryhtyy satamaan.

* Ryhtyy tulemaan kevät.

Toinen alkaa-verbi taas saa lausesubjektin, mikä mahdollistaa eksistentiaalilauseet komplementtina:

40. a Pihalla alkaa juosta poikia.

b Alkaa sataa.

c Alkaa tulla kevät.

Lauseissa (35) - (38) voisi kúvitella lokaali-ilmaulksen nostetun koko jalon alkưn säännöllä, kuin millä subjekti on nos-

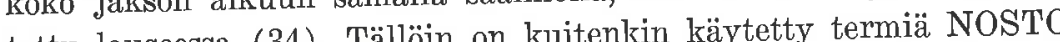

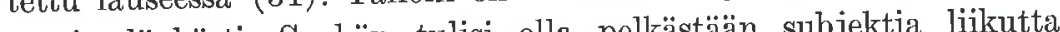
va sääntö. Todennälöiscmpi selitys näille virkkeen alkuun siirretyille konstituenteille on, että ne on kuljettanut paljon myöhempi siirtotransformatio, joka ei vaikuta komplementilauseen sieiisen trenter ken

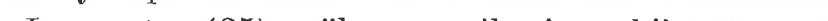

Lanse (35) nakyy se ilmeisen Kifstatomasti hyäksytty seikka, etta suomessa on myös kalsi nayltaa-verbià. Toinen saa henkilösubjektin kuten lauseessa 41, toinen lausesubjektin, kuten on lai lauseissa (35) sekä (42)

41. Poika näyttää kieltään.

42. a Poika näyttää olevan vilustunut.

b Poika näyttää sairaalta.

Lause (36) havainnollistaa hyvin NOSTOn pakollisuutta. Infinitiivillä ei suomessa ole passiivia sattuu-verbi taas on 1-paikkainen eli saa vain lausesubjektin. Passiivinen subjektiaines on siis nostett syö-verbin subjektin paikalta sattuu-verbin subjeltiksi. Kiintoisa on, että silloinkin kun passiivi voisi jäädä upotettuun lauseeseen (kun kyseessä on partisiippirakenne), puhekieli pyrkii kopioimaan sen redundantisti matrisilauseeseen: lause (43 a) on vähemmän luonteva ja puhekielenomainen kuin lause ( $43 \mathrm{~b}$ ).

43. a Täällä näkyy juhlittavan.

b Täällä näytään juhlittavan.

Kuten esimerkeistä (34)-(38) näkyy, NOSTOn soveltamisen jälkeen ei ratkea mitenkään automaattisesti, millaisen ei-finiittise muodon komplementtilause saa. Suomessa on valittavana kolme vaih toehtoa: ta-infinitiivi, ma-infinitiivi sekä 1. partisiippi (van tai neen). A-verbit ryhmittyvät näiden mukaan seuraavasti.

$\begin{array}{lll}\text { ta-infinitivivi } & \text { ma-infinitivi } & \text { partisiippi } \\ \text { alkaa } & \text { lakkaa } & \text { kuuluu } \\ \text { mahtaa } & \text { rupeaa } & \text { näyttää } \\ \text { saattaa } & \text { sattuu } & \text { näkyy } \\ \text { taitaa } & \text { tuppaa } & \text { tuntuu } \\ \text { tahtoo }(\neq \text { haluaa) } & \text { joutaa } & \text { vaikuttaa } \\ \text { ehtii } & \text { ehtii } & \end{array}$


Kahden ensimmäisen ryhmän välillä on vaikea havaita semanttista (littyviă verbejä.

\subsection{Modaaleista}

Tällä hetkellä generatiivisessa semantiikassa lienee vallitsevana syntaktis-semanttinen tulkinta. Ensinnäkin modaaliverbeillä rianteilla on ns. juuritulkinta. Modaalilla voi katsotaan olevan kolme juurimerkitystä: lause (44) on näin ollen kolmiselitteinen, ja sen synonyymeja ovat lauseet (45)-(47).

44. Pekka voi nostaa täyspalkkauksen. $=$

45. Pekka pystyy nostamaan täspalka

46. Pekka saa nostaa taysspakkauksen.

47. Pekan sopii nostaa täyspakkaus.

Voi siis olla kyse Pekan kyvystä (45), luvasta, jolloin lause on daikka muuten vain tüy päinsä, ett: sissa Pekkaa voi nitä̈̈ modaalin subjekti-NP:nä jo syvärakenteessa. Pintarakenteeseen päästään soveltamalla EKVIä.

Samanlainen juurimerkityksen kolmijako voidaan tehdä täytyy verbistä. Lauseella (48) on synonyymeinaan lauseet $(49)-(51)$.
48. Pekan täytyy nostaa täyspakkaus. $=$
49. Pekan on pakkko nostaa täyspakkka
50. Pekan pitää nostaa täyspakkaus.
51. Pekka joutuu nostamaan täyspakkauksen.

Tässä voi olla ensinnäkin kyse siitä, että Pekalla on sisäinen pakko toimia mainitulla tavalla (49). Toiseksi voidaan todeta, että ky seessä on Pekan velvollisuus (50); tämä on deonttinen tulkinta. Kolmanneksi voi olla niin, että Pekka olosuhteiden pakosta nostaa

$5 \mathrm{v}$. Wright (1957): "There are the deontie modes or modes of obligation These These are concepts such as the allowed to do), and the forbidden (that which we must not do)." mainitun pakkauksen (51); tässä merkityksessä täytyy-verbin synonyymina suomessa on verbi joutuu. Nykysuomessa täytyy-verbi ei saa lainkaan nominatiivissa olevaa henkilösubjektia ; ${ }^{6}$ kuviteltavissa kuitenkin on, että se on juurimerkityksessään kaksipaikkainen niin kuin voi-verbikin. Juurimerkitysten lisäksi näillä modaaleilla on toinenkin, ns. episteeminen tulkinta. Tämän tulkinnan mukaan lause (52) merkitsee samaa kuin esimerlkkien (53) ja (54) parafrasit.

52. Pekka on voinut nostaa täyspakkauksen.

53. Pekka on saattanut nostaa täyspakkkauksen.

54. Tietääkseni on mahdollista, että Pekka on nostanut täyspalssauksen.

Modaalin käyttäjän, puhujan tiedossa ei ole mitään, mikä pitäis Pekan nostopuuhia mahdottomina; hänen kannaltaan on mahdollista että Pekka on pakkauksensa nostanut. Samalla tavoin tulkitaan toinenkin modaali: Lauseella (55) on parafraasi, joka havainnollistaa tätä episteemistä merkitystä.

55. Pekan on täytynyt nostaa täyspakkaus.

56. Tietääkseni on välttämätöntä, että Pekka on nostanut täyspakkauksen.

Tässä on siis kyse puhujan päättelystä. Sen todistusaineiston perusteella, jota puhujalla on käytettävissään, näyttää välttämättömältä, että Pekka on nostanut täyspakkauksen.

Episteemisissä tapauksissa on syntaktinen analyysi kummankin modaalin suhteen sama: kyseessä on ylksipaikkainen predikaatti, joka saa lausesubjektin. Kuten todettua, puhuja esittää jonkin proposition, jonka hänen mielestään pitäisi kaiken todennäköisyyden mukaan olla tosi taikka joka voisi olla tosi , hän ei csitä mitä̈n lausecn subjeltipersoonan voimisesta tai täytymisestä. Lähtömuoto on tïmënnäköinen:

- Täytyy-verbin ja sille lähimerkityksisten verbien rektioiden historiallisesta

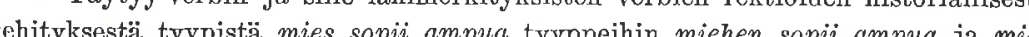
sopii ampumauan ks. Saulkonen (1965) s. 121-147. 


\section{Voi [Pekka on nostanut täyspakkauksen]}

Jotta päästäisiin pintarakenteeseen, tarvitaan NOSTOa, joka siirtää NP:n Pekka modaalin subjektiksi. Seuraava esimerkki havainnollistaa sen, että NOSTOa voidaan joutua soveltamaan useita kertoja peräkkäin, se on luonteeltaan syklikaalinen eli kierrossääntö: Lauseessa (58) sitä on täytynyt soveltaa kahdesti, koska vain alimmaiseksi upotetun lauseen verbi tuntea on sellainen, joka saa henkilösubjektin.

58. Pekka voi näyttää tuntevan Liisan

Tümän rakenteen voi kuvata seuraavalla puudiagrammilla:

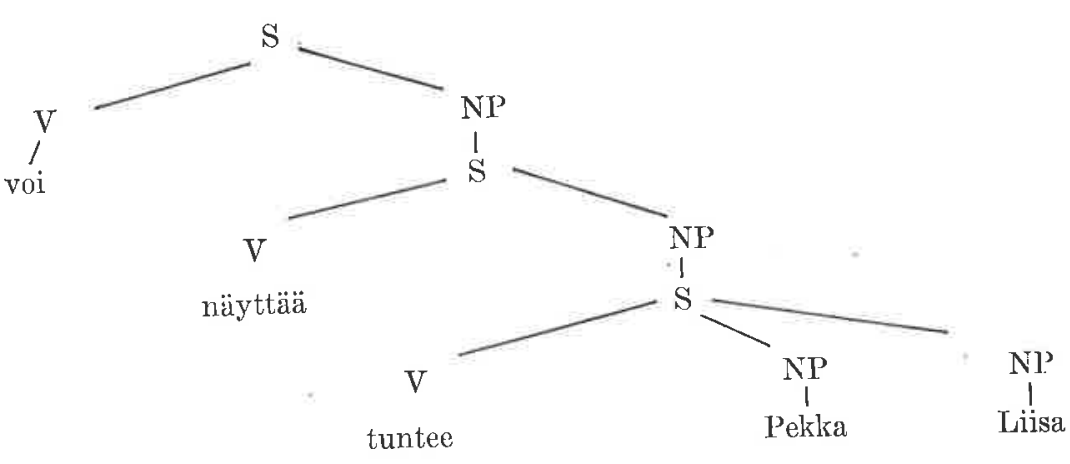

Modaalien mainittu monimerkityksisyys ei useinkaan aiheut Modaalien mainitu monisa tapauksissa. Niinpä lause (59) vo s. lia tä tähtömuotona on (59a), jälkimmäisessä (59 b)

59. Täällä voidaan syödä omena.
59 a: juurimerkitys

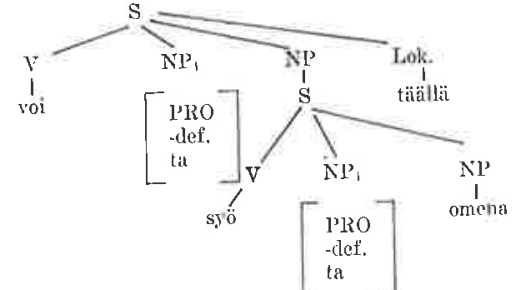

$59 \mathrm{~b}$ : episteeminen

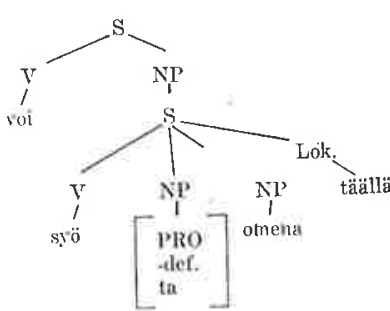

Kaikki rakenteet eivät kuitenkaan ole tâllä tavoin kalksiselitteisiä. Polyseemiudesta voi olla siis syntaktisia seurauksia pintarakenteeseen saakka. Esimerkiksi sellainen geneerinen lause, josta puuttuu ilmi pantava pronomini pinnasta, sallii siihen liitetylle modaalille vain juuritulkinnan. Tästä syystä lauseille $(60 \mathrm{a}-\mathrm{b})$ esitetyt episteemiset parafraasit $(61 \mathrm{a}-\mathrm{b})$ ovat epäkieliopillisia.

60. a Siellä täytyy osata ruotsia.

b Kesalla voi uida joka päivä

61. a *Tietääkseni täytyy olla niin, että siellä osaa ruotsia.

b * Tietääkseni saattaa olla niin, että kesällä ui joka päivä.

Syynä epäkieliopillisuuteen on "kadonnutta henkilöä" koskeva rajoitus: se ei voi esiintyä missä tahansa komplementtilauseessa, paitsi jos se esiintyy myös matriisilauseen subjektina. Episteemisellä modaalilla taas, kuten todettiin, ei voi olla henkilösubjektia siis matriisilauseessa ei ole kadonnutta henkilöä ja episteeminen tulkinta on mahdoton.

Tarkastellaan nyt, miten on eksistentiaalilauseiden laita näiden modaalien suhteen. Niissähän ei ole johdon tässä vaiheessa enää henkilösubjektia (vrt. ed.). Odotuksenmukaista olisi, että ainakin episteeminen tulkinta olisi mahdollinen, jos eksistentiaalilause on modaalin subjektina. Esimerkin (62) lauseet voidaan tosiaan tulkita episteemisesti:

62. a Pihalla voi juosta poikia

b Liiisalla voi olla auto.

Mutta ilmeistä on, että näillä lauseilla on myös deonttinen, sallimista merkitsevä tulkinta:

63. a Pihalla saa juosta poikia

b Liisalla saa olla auto.

Sen sijaan voi ei näissä rakenteissa saa merkitystä 'pystyä', mikä käy ilmi seuraavien lauseiden epäkieliopillisuudesta

64. a * Pihalla pystyy juoksemaan poikia

b * Liisalla kykenee olemaan auto.

Näyttää siis siltä, että sisäisen kyvyn ollessa kyseessä lauseen täytyy olla nominatiivisubjektillinen. Deonttinen voi, samoin kuin 
cag, edellyttö̈ että lauseessa ei ehkä syvärakenteessa olekaan sub-

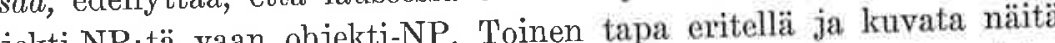
jekti-NP: tã vaan objoti-No on Postalin (mt.) esittämä verbien hienohkoja semantisia eroja on Pötä rerbit sisältävä rakenne on permit ja allow 'sallia' analyysi. Namă verbit sisaltala rakente on kaksiselitteinen sen makan, antijo pu. julekulle kolmannelle henkilölle (taikka esittääkö hän vain yleisen luvan).

"The core meaning of allow is neutral with respect to how the "permission" is expressed. ... An optionally associated assumption with inAIsTesses his permission to the individual possessing individual expresses his pe

Fyysistä pystymistä merkitsevänä modaalilla ei ole tätä vaihtoTyysicte ehtoa. Kort kuta lauseidce (tatkaisua, että ko. sääntaa semanttiscksi lio toôn voisi valinainsti välille tulisi riippumaan tälepisteemisen ja deonttisents.

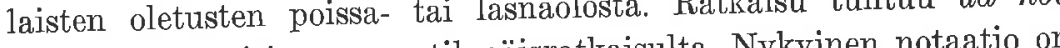
-tyyppiseltă, toisin sanon tilapaid toisaalta liian karkea pystyäkseen ilmentanaan esia lyseesi on ti-

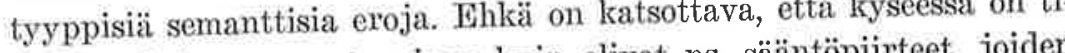
lapäsratkaisu, samantapeng käyttö edelsi derivaationrajoituksia

tiï täytyy-verbin tapauksess KOSTOa, koska ko. verbi saa vain lausesubjektin:

$$
\text { täytyy } \underset{\text { NP S }}{\text { [asia ratketa] }}
$$

Tämä ratkaisu tuottaa hyviä pintarakenteita, mutta se herättäa Tämä ratkaisu tuottan hï se ei ole subjektintuottamissääntö, jolpari ongelmaa. Ensin so tuottaa datiivigenetiivin lainen edella kave No N jota Siro (1964, s. 97) sanoo agentiksi. NÖLo-saannön mäksyän, voi-

T Ks. Postal (1972) s. 156 daan todeta, että lauseessa (65 a) on sovellettu subjektinnostoa, lauseessa $\left(65\right.$ b) ei, koska eksistentiaalilauseessa ei ole subjektia. ${ }^{8}$

65. a Poikien täytyy juosta pihalla.

b Pihalla täytyy juosta poikia.

Mutta, kuten aikaisemmin olen todennut, täytyy-verbillä on myös juuritulkinta, joka edellyttäisi semanttisesti, että jo lähtörakenteessa sillä olisi henkilösubjekti (tai -agentti). Tällöin kyseessä ei olisi NOSTO, vaan EKVI - joka muuten on ainoa mahdollinen adjelstiivirakenteista:

66. a Poikien on hauska juosta pihalla.

$\mathrm{b}$ * Pihalla on hauska juosta poikia.

Mikä olisi sitten vaihtoehtoinen ratkaisu? Nähdäkseni se, että täytyy-verbin tapauksessa tarvittaisiin kaksi sääntöä, genetiivistäminen ja sitten toinen siirtosääntö, joka vie genetiivimuotoisen NP:n koko lauseen alkuun. Tämä sääntö soveltuu muihinkin henkilöNP:ihin ; ellei agenttia ole, se siirtää objektin:

67. Pojat täytyy tuoda pihalle.

Tässä vaihtoehdossa puolestaan on se ongelma, että nämä kaksi sääntöä yhdessä vaikuttaisivat upotetun lauseen lausemaisuuden menetykseen. Näin ei lavenisi sä̈̈nnön ala, kuten edellisessä tapayksessa, vaan tulisi kolmas infiniittistämisen aihe.

Ennen kuin siirryn käsittelemään NOSTO-säännön toista puolta (subjektista objektiksi), puutun vielä lyhyesti toiseen täytyy-modaalin yhteydessä ilmenevään asymmetriaan. Kuten tunnettua (ja historiallisesti ymmärrettävää), siihen ei voi liittää passiivin päätettä. Koska nykysuomessa ei ole passiivin infinitiviä̈kään, herää kysymys, ovatko passiivi-ilmaulsset yllä mainittujen verbien yhteydessä mahdottomia. Kyseessä olisi ei-semanttinen tuotosrajoitus (output condition). On huomattava, että voi-modaalinkin ollessa kyseessä merkitysero geneerisen, kadonnutpersoonaisen lauseen ja passiivilauseen välillä on vähäinen, kuten esimerkistä $(60 \mathrm{a}-\mathrm{b})$ huomaa.

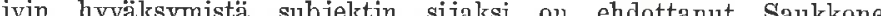


68. Tässä laitoksessa täytyy puhua englantia.

69. a Tänä̈̈̈n voi puhua suomea.

b Tänä̈n voidann puhua suomea.

Tilanteen mukaan lauseissa $(69 \mathrm{a}-\mathrm{b})$ voidaan tarkoittaa aivan samalla tavoin rajattua hen vilillä mahdollisesti havait-

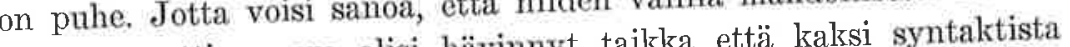
tava semanttinen ero olisi lavilo taloksen (68), olisi löydettävä pohjamuotoa tuottaisivat kn esimerkkeja, joissa sekă passivi etta tajlyei käy yksikön kolmannessa persoonassa. Lieven pi täytyy ja passiivi käyttäytyisivă yhdella tapaa, voi toisella. ${ }^{0}$ Mikáli seuraavissa esimerkeissä b-lauseet ovat parempia kuin c-lauseet, esimerkit kelvannevat todisteiksi, sillä monikollinen predikatiivi ta adverbiagli käy passiivissa ja täytyy-tapaulksissa; geneerisissä e.

70. a Täällä pysytellään terveinä. b Täällä täytyy pysytellä tervein c * Täällä voi pysytellä tervein

d * Täällä pysyttelee terveinä.

.

$$
\text { c " ? voi palata }
$$

ilmoitetaan, onko syytä huoleen.

7. a Hallituksen $t$

täytyy ilmoitta

* voi ilmoittaa

Tun lauseessa on sellainen adverbiaali, joka rajaa mahdollisten Kun lauseessa on sellainen advnut henkilö saa eri alan (seope) tekijäin määrän, geneerinen kadonnut

73. Kaikkialla maailmasse (pohditaan, mitä voitaisiin tehdä. $\left\{\begin{array}{l}\text { pohditaan, } \\ \text { täytyy pohtia }\end{array}\right.$

$$
\begin{aligned}
& \text { täytyy poht } \\
& \text { voi pohtia }
\end{aligned}
$$

on parafraasi on pakko voidaan tulkita joko passiiviksi tai geneeriseksi (Luomi 1972).
74. Pääkirjoituksissa $\left\{\begin{array}{l}\text { esitetään hallitulksenvastaisia mieli- } \\ \text { piteitä. } \\ \text { täytyy esittää }\end{array}\right.$

75. Opettajakunnassa $\quad \begin{gathered}\text { voi esittää } \\ \text { käsitellään uutta koulujärjestystä. }\end{gathered}$ $\left\{\begin{array}{l}\text { käsitelaän uutta } \\ \text { täytyy käsitellä }\end{array}\right.$

$$
\text { , } \quad \text { voi käsitellä }
$$

Passiivin päätteen poisjääminen modaalista aiheuttaa siis ainakin osittaista kaksiselitteisyyttä täytyy-verbin sisältämiin rakenteisiin.

\subsection{Onko NOSTOa objektiksi suomessa?}

Kohdassa 2.2 totesin, että jotkut 1-paikkaiset, lausesubjektin saavat verbit eivät salli infiniittistä komplementtia, vaan että-lause on niiden ainoa mahdollinen subjekti. Samaten on olemassa pien ryhmä sellaisia 2-paikkaisia verbejä, jotka saavat objektikseen vai ralienteen se että S, eivät koskaan partisiippirakennetta. Seuraavassa on kolme tällaista ryhmää:

$\begin{array}{lll}\text { häpeää } & \text { päättää } & \text { ehdottaa } \\ \text { katuu } & \text { säätää } & \text { määrittelee } \\ \text { kestää } & \text { valvoo } & \text { tarkoittaa } \\ \text { sietää } & & \text { uhkaa } \\ \text { ottaa huomioon } & & \text { merkitsee } \\ \quad \text {, varteen } & & \end{array}$

Näistä ei muodostu mitään selviä semanttisia luokkia. Varsinkin ensimmaisesta

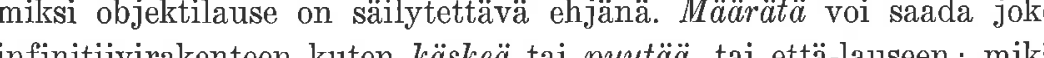
infinitiivirakenteen kuten käsheä tai pyyläă, tai että-lauseen; mikä nämä erottaa saątámisestă ja valvoisesta, en osaa sanoa. Sanomisverbit voivat esintya partisippiralenteen kera kahta poikkeusta lukuun ottamatta: ehdottaa ja uhata. Näiden suhteen saattaa ku tenkin esiintya puhujakohtaisia eroja.

Partisiippirakenteita on käsitelty lauseopillisessa kirjallisuudessa jonkin verran. Ainakin kaksi avointa kysymystä kannattaa silti ottaa esiin: toinen on akkusatiiviobjektin vaihtelun ehdot ja toinen koskee partisiippirakenteen oletettua historiaa. Tutkimuksessaan suomen akkusatiiviobjektista Wiik päätyy seuraavanlaiseen loppurat- 
kaisuun, Suomessa on akkusatiivisääntö, joka lisää objektina oleviin

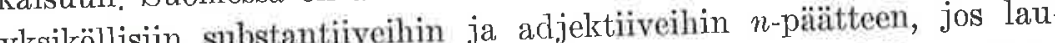

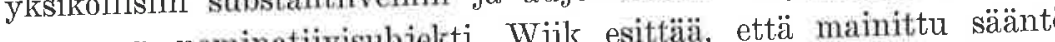
seessa on nominativistoji kitä ennen sovelsijoittuu intersyktikaaliseksi eli kierta sääntöjä kuten EKVIä, SUFletaan infinitiviralenteila cuaron FIKSOINTIa, NOSTOa ja KARSINTAa (pruing), ja sen jatken partisipinmuodostamissachtoja, min. Nos ja KARSINTAa. Nama ryhmă erottuvat hanen maan siten, ettäa "konjunktiot" ta (= I int:n tunns) ja ma (- III inf:n tunnus) ovat "heikkoja" ja saavat setraavan lausen oits mot. mään lausemaisuutensa. Sen sijaan partisiipin mekk, konjunktio $A$ on "vahva", se pysyttää partisippirakenteen kauemmin lausemaisena kuin infinitiivin. Tämä oilkean tuloksen tuottava, joskin tekmaisena kuin intinition ratkaisu tarvitaan, jotta saataisiin johdetuksi oikein seuraavat lauseparit:

\section{6. a Miesten uskotaan ampuvan suden}

b Miesten sallitaan ampua susi.

77. a Olettakaa pojan ampuvan karhun

b Käskekää pojan ampua karhu.

NP miehet lausetta ( 76 a) johdettaessa on vielä nominatiivissa, un akkustiviväntö (76relletgan, ja se nostetaan matriisilausee-

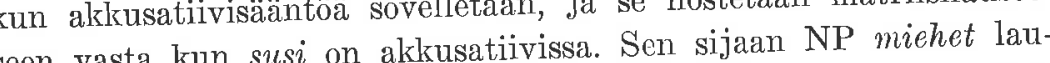
seen vasta kun susi on akkusatiivissa. Sen eseen ennen akkusatiiviseessa $(76 \mathrm{~b}$ ) on jo siirretty matrisilause alemmassa lauseessa enäż saännön soveltamista, jota sovellettai jäa ennalleen.

Intersyllikaalista saantoa ei transformaatioteoriassa ole aikaisemin esitetty: tähän saakka on tuntunut tarpeelliselta olettaa erä säännöt kierroksia edeltäviksi, jotkin toiset (esim. siirtosaănnöt) postsyklikaalisiksi eli kierrostenjälkeisiksi; kahden kierroksen käsit on tuntematon. Jotta tällaisen melko tuntuvan teoreettisen uudento todistusaineistoa, joka on tästä nkipumaton. Onko kahden kierrokse suomen ylssisyistap atkaisu siihen, että lausemaisuutta tuntuu oleolettaminen ain

Jos lastetan

os lähdetään siitä, että suomessa ei ole NOSTO-sääntöä muuta (Wiikillä on kaksi eri nostoa), tällöin

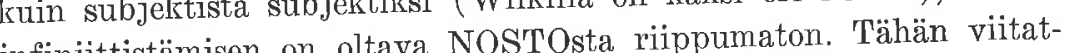

tiin jo alussa, kohdassa 2.1. Tällöin ei krummassakaan lauseessa ( 76 a-b) olisi kyse NOSTOsta vaan genetiivistämisestä. Lauri Karttunen ${ }^{10}$ on ehdottanut Wiikin ratkaisuun vähäisen muutoksen, jonka ansiosta voidaan luopua mielivaltaisesta kahden kierroksen ajatuksesta. Wiik puhuu heikoista ja vahvoista subjekteista. Edellinen on $\mathrm{mm}$. passiivin $t a$-pronominiaines, joka ei koskaan pääse leksikaalis-

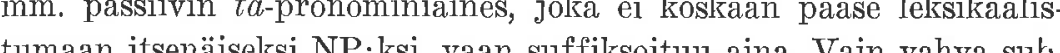
tun. Jelti (lectisen.

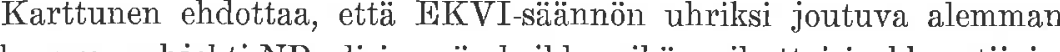

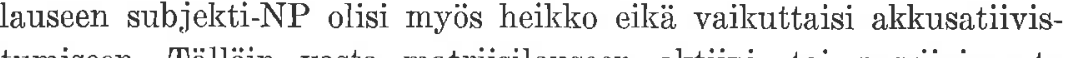
tumiseen. Tallon vasta matiisilauseen alstivi tai passivimuoto ratkaisisi, tuleeko objektista paâtteellinen vai ei. Vahroja subjekteja olisivat paitsi leksikaaliset NP:t myös "kadonneet henkilöt". Sanotaanhan aina (78)

78. jos haluaa ampua suden,...

Tällä tavoin sääntö (79) pitää paikkansa myös yhdyslauseisiin:

79. Pidennä akkusatiivi, kun lauseessa on vahva subjekti-NP.

Hinta, joka tästä luonnollisen tuntuisesta ratkaisusta on maksettava, on kyllä sekin huomattava. Se nimittäin edellyttää, että sekä täytyy-verbin että antaa ja sallii -verbien rakenteet selittyvät EKVIsäännöllä, ts. seuraavissa lauseissa on sovellettu EKVTä.

\section{0. a Miesten sallitaan ampua susi.
b Miesten täytyy ampua susi.}

ällaisessa ratkaisussa menetetään mahdollisuus esittää semanttisia eroja syntaktisin keinoin, kuten aikaisemmin olen jo todennut. EKVI ei tuntuisi myöskäään käyvän niissä tapauksissa, joissa sallii ja anta saavat lauseobjektin

81. a Junala sallii sataa

b Mikko antoi pihalla juosta poikia.

Nämä eivät täytä EKVI:n soveltamisehtoja (oltava objekti-NP myös matriisilauseessa). Kolmas ratkaisu, ja historiallisesti helpoin

\footnotetext{
${ }^{10}$ Luennolla huhtikuussa 1973
} 
pervetelä sain infinitiivirakenne syntyy soveltamalla perustella olisi se, etta vain in samalla NOSTO-saäntoa. Verbit salu, ana käiden rektioon kuuluu getavoin kuin 1-paikkainen verbi täylyy. Nalden rijan ei irrota yhtï netiivimuotoinen NP. Partisilppirakenne sen sijant ei irrota yht jäsentään hallitsevan lauseen jäseneksi, vaan saily Siä enen añ lau-

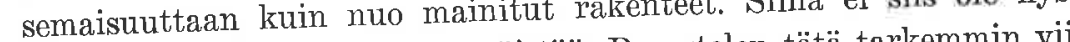
NOSTOsta, toisin kuin Wiik väittää. Perustelen tătä tarkemmin vilmeisessä luvussa.

3.2. Upotettuna nominaalilause

Jos upotettuna lauseena on ns. nominaalilause, suomessa on ny(a) ottä-lause, partisippikyään kolme vaihtoehtoista ilmausta tarjolla: ettá-lause, partisiippirakenne sekä translativin sisaltáa take näiden ilmausvaihtoehtojen välinen merkitysero on tuskin havaittavissa - näin on esim. lauseissa ( $82 \mathrm{a}-\mathrm{c})$

82 a Agnew väitti, että tiedot ovat perättömiä.

b " tietojen olevan perättömiä.

$$
\text { c " " tietoja perättömiksi. }
$$

Tällaista synonymiaa ei kuitenkaan esinny kaikkien verbien yhTeydessä. Että-lause ja partisiippirakenne ovat synonyymisia; niiden ero on niin sanoakseni funktionaalinen. ${ }^{11}$ Että-lauseen ja translatiivirakention olla myös semanttinen. lativirakenteen ero taas alkaa nöiti osittain melko heiveröisiä seSeuraavassa yritan tavoittaa naita osittain me kirjallisen yleissuomanttisia eroja, joiden

Vaikka translatiivirakennetta eivät kaikki luekaan ns. lauseenvastikkeiden joukkoon (vrt. Ikola 1971), esimerkki (82 c) on kuivassiki johdettava kaksi lausetta käsittävästä syvärakenteesta, silli

${ }^{11}$ On operaatioita, joiden suhteen että-lause on "saareke" (island) - joiesim. kysymystan

Millainen hän tuntuu olevan?

T'ekijüi on käsitellyt ailletta, väittää on verbi, joka vaatii lauseobjektin. Koko (82):n lähtömuoto on siis $\left(82^{\prime}\right)$.

82'. Agnew väitti [tiedot perättömiä]

Tässä oletetaan, että kopulaa ei esiinny lähtörakenteessa, koska se on vailla omia semanttisia piirteitä. Vain jos tarvitaan morfeemia johon modus-, tempus- tai kongruenssiaines voisi liittyä, olla-verbi pääsee pintaan, saa lekssikaalisen ilmiasun. Vain merkitylkesë̈ ,

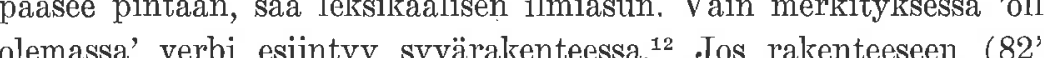
olemassa' (8) verbin objektiksi. Upot predikaattiosa muuttuu translatiiviin.

Mutta translatiivirakenteita, aivan kuten aikaisemmin infinitiivirakenteita, tuotetaan myös toista sääntöä, nimittäin EKVIä soveltamalla. Niissä tapauksissa, joissa hallitsevan lauseen verbi saa konkreettisen objektin, tästä prosessista on kysymys

83. a Jalka hierottiin terveeksi.

Mies joi lasin

Kitkijä oikaisi selkänsä̀ suoralssi.

Kustaa Vaasa huudettiin kuninkaaksi.

Partio otettiin vangiksi.

b Lausun teidät tervetplleiksi.

Nimitän teidät yp. lehtoriksi.

Vihin tämän kirkon Jumalan temppeliksi.

Miestä kritettiin / moitittiin strulkturalistiksi.

Nämä verbit ovat suoritusta tai saavutusta ilmaisevia; ne eivät sen sijaan saa objektia, joka kuvaisi tilaa tai toimintaa. Näissä tapauksissa että-lause ei ole mahdollinen, ja EKVI-sääntöä on pakko soveltaa. b-ryhmän toimintaverbejä on Austinilta saadulla termilla alettu nimittaă performativisisiksi. Ne ovat verbejä, joiden avulla jokin toimenpide suoritetaan. ${ }^{13}$

${ }^{12}$ Vrt. esim. Lyons (1968). Borkin (1973) on sitä mieltä, että c-lauseen tapauksessa olisi kyse olla-verbin poistosta. Itse semanttisin havaintoihin tän

kin lauseobjektin ja NOSTOn; hunto voi selittyä kummalla tahansa tavalla. 
Tämän luvun ensimmäinen esimerkki (82) osoitti, että esim. sanomisverbin yhteydessä molemmat rakenteet käyvät eikä merkityseroa ole havaittavissa. Samalla tavoin toimivia verbejä ovat siis sanoo, mainitsee, osoittaa, päättelee, todistaa, tunnustaa, kaikki semi- tai ei-faktiivisia. ${ }^{14}$ Toisin sanoen jos tällainen verbi esiintyy hallitsovassa lauseessa, upotettua lausetta ei edellytet to toksi. Voihan väittäö tai päätellä mitت̈ tahang ilman ettö väitettö tarvitsec colly

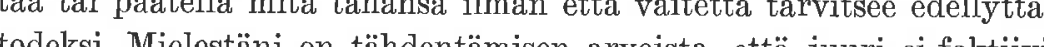
slla verbeille on kumpilin che ver

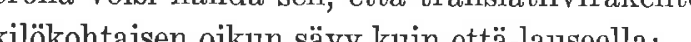
ilökohtaisen oikun sävy kuin että-lauseella

84. Sanoin häntä maisteriksi, vaikka tiesin, ettei hän ollut edes kandidaatti.

On kuitenkin joitakin sanomisverbejä, jotka vaativat objektikseen ehjän proposition. Nämä verbit ovat faktiivisia, siis ne edellyttävät että-lauseen todeksi ja esittävät jonkin kommentin ao. lauseesta:

85. a (?) Myönnän asian päivänselväksi

b * Syytetty kielsi Pekan veljekseen

c * Puhuja korosti marxilaisuuden keskeneräiseksi teoriaksi

Tässä suhteessa verbit ovat samanlaisia kuin edellä kohdassa 3.1 mainitut emotiiviset faktiiviverbit häpeä̈, harmittelee, katuu, jotka eivät myöskään voi saada objektikseen muuta kuin ehjän että-lauseen.

Olen nyt tarkastellut toimintaverbejä ja sanomisverbejä. Seuraavaksi ryhmäksi otan tahdonilmausverbit, joita ovat esimerkiksi seuraavat.

$\begin{array}{ll}\text { optatiivisia } & \text { imperatiivisia } \\ \text { haluaa } & \text { vaatii } \\ \text { tarvitsee } & \text { käskee } \\ \text { aikoo } & \text { neuvoo } \\ \text { toivoo } & \text { pyytää } \\ \text { odottaa } & \end{array}$

${ }^{14}$ Termiä ovat ensinnä käyttäneet Paul ja Carol Kiparsky (1970). Sitä o pidä sekoittaa meillä vanhastaan küytettyyn
Tahdonilmausverbit voivat saada kummankin rakenteen objektikseen:

\section{6. a Toivon, että olisit toverini.}

b Toivon sinua toverikseni.

87. a Kansalaiset haluavat, että hammashoito olisi ilmaista. $\mathrm{b}$ hammashoidon ilmaiseksi.

88. a Sorsa pyysi Grönbergiä sihteerikseen.

b " että Grönberg $\int$ olisi hänen sihteerinään. tulisi hänen sihteerikseen.

Optatiivisen merkityksen sisältävät tahdonilmausverbit saavat vain hyvin harvoja translatiivirakenteita. Adjektiivi tuntuu mahdottomalta, kuten seuraavista esimerkeistä ilmenee.

$$
\begin{aligned}
& \text { 89. a * Odotan kokousta hyödylliseksi. } \\
& \text { b * Mies toivoi minua lihavaksi. }
\end{aligned}
$$$$
\text { c * Haluan hänet avuliaaksi. }
$$

Translatiivirakenne tuntuu edellyttävän, että hallitsevan lauseen henkilösubjekti voisi verbin ilmaisemalla toiminnalla jotenkin vaikuttaa komplementtilauseen ilmaisemaan tulokseen; jostakin syystä on realistisempaa toivoa jonkin roolin muuttumista kuin muutosta laadussa Mutta sellaisissakin tapauksissa, joissa kumpikin rakenne käy, merkitysero on näkyvissä:

$$
\text { 90. a Haluan, että }\left\{\begin{array}{l}
\text { olet vaimoni. } \\
\text { olisit }
\end{array}\right.
$$

b Haluan sinut vaimokseni.

b-lause vastaa merkitykseltään vain konditionaalivaihtoehtoa. Toinen verbiryhmä, imperatiivin parafraaseiksi soveltuvat verbit, eivät myöskään voi saada mitä tahansa translatiivirakennetta, vaan ainoastaan toimintaa ilmaisevan:

\section{1. a * Sorsa pyysi Grönbergiä demokraattiseksi. \\ b * Isännöitsijä pyysi minua siistiksi.}

c * Locke ei vaadi ihmisiä yhtä varakkaiksi.

Näistä lauseista tulee kieliopillisia, jos niihin sijoitetaan ollaverbin infinitiivi näkyviin. Tässä saattaakin olla kyseessä kolmas olla-verbi, joka ei ole tyhjä kopula. 
Siirryn nyt käsittelemāan kognitio- eli aivotoimintaverbejä, joilla myös on kaksi vaihtoehtoista objektirakennetta. Seuraavassa tärkeimmät tällaiset verbit:

$\begin{array}{ll}\text { ei-fakttiivisia } & \text { faltiivisia } \\ \text { ajattelee } & \text { tietää } \\ \text { kuvittelee } & \text { ymmärtää } \\ \text { luulee } & \text { unohtaa } \\ \text { uskoo } & \text { muistaa } \\ \text { pelkä̈̈ } & \text { arvaa } \\ \text { epälee } & \end{array}$

Lauseet $(95 \mathrm{a}-\mathrm{b})$ voidaan katsoa synonyymisiksi siinä merkityksessä, että ne molemmat merkitsevät subjektipersoonan yksityisä kuvitelmaa, jonka ei tarvitse pitää paikkaansa ulkoisessa todellisuudessa. Tâmăn lisäksi että-lauseella on nähdäkseni toinenkin tulkinta: subjekti pohdiskelee jotakin yleisesti hyväksyttyä tosiseikkaa.

92. a Ajattelen aurinkoa kuumaksi (= kuvittelen).

b Ajattelen, että aurinko on kuuma (=1. kuvittelen

2. pohdin sitä)

Joskus merkitysero on vielä selvempi; tällöin translatiivirakenteeseen sisälttyy merkitys, että ajattelemisella on vaikutusta lopputulokseen.

93. a Häntä ajatellaan tulevaksi presidentiksi (=suunnitellaan) b Ajatellaan, että hän on tuleva presidentti.

Jos että-lause ilmaisee ajattelemisen objektiivisen sisällön, ilman että korostetaan ajattelun subjektiivisuutta, translatiivirakenne ei käy. Lause $(97 \mathrm{~b})$ on tulkittavissa vain siten, että ajattelu on osoitettu jäljestäpäin virheelliseksi.

94. a Ajattelin surullisena, että mummo on viimeinen kamassi. b Ajattelin surullisena mummon viimeiseksi kamassiksi.

Verbit luulee ja uskoo ovat ei-faktiivisia, ja niiden yhteydessä sekä lauseobjekti että translatiivirakenne ilmaisevat luulijan henkilökohtaista kantaa pikemminkin kuin mitään yleisesti pitävää totuutta. Niiden väliset läyttöerot ovat hienonhienoja; tässä voi hyvin vallita intuitioiden kirjavuuttakin. Joskus voi kyseessä olla pelkkä tuotosrajoitus:
95. a Luulin Tommia sinuksi.

b * Luulin, ettë Tommi oli sinä.19

Seuraavissa kysymyksissä on kuitenkin selvä painotusero: alauseet ilmaisevat kiinnostusta pikemminkin luulijaa kohtaan, blauseet luulemisen sisältöä kohtaan:

96. a Luuletko häntä viisaaksi?

$\mathrm{b}$ Luuletko, että hän on viisas?

97. a (?) Luuletko Kaisaa kyllästyneeksi mieheensä?

b Luuletko, että Kaisa on kyllästynyt mieheensä?

Edelleen kysymykseen, miksi joku on ollut poissa, todennälköisempi ja loontevampi vastaus on että-lause kuin translatiivirakenne.

98. a Miksi opettaja ei ollut tänä̈n tunnilla? b Luulen, että hän on sairas.

c (?) Luulen häntä sairaaksi.

Siirrymme nyt faktiivisiin aivotoimintaverbeihin. Taas suuri osa tapauksista on synonyymisia. Esimerkin (102) lauseiden välillä ei ole merkityseroa.

99. a Tiedetään, että hän on kunnon mies.

b Hänet tiedetään kunnon mieheksi.

Seuraavissa esimerkeissä sen sijaan kaikissa b-lauseet tuntuvat vanhahtavilta tai jopa luonnottomilta. Verbin faktiivisuudesta johtunee, että translatiivirakenne on useimmiten tarpeeton. Luontevimmillaan se on jonkinlaista henkilökohtaisen tiedon inventoimista (vrt. 106).

100 a Isä ei tiedä vielä, että olet maisteri $\mathrm{b}$ * Isä ei tiedä vielä sinua maisteriksi.

101. a Tietävätkö naapurit jo, että uusi automme on Volvo b " "uuden automme Volvoksi?

102. a Tiedän, että se on lähes uskomatonta.
b ? Tiedän sen lähes uskomattomaksi.

103. Tiedän tiaisen linnuksi ja hauen kalaksi. 15 Minun kielikorvani mukaan tämä ei merkitse samaa kuin lause Luulin,
että Tommi olit sinä (= Luulin Tommiksi sinua). Vrt, kuitenkin Ikola (1973). 
Samantapaisesti käyttäytyy ainakin useiden ihmisten intuitioiden mukaan ymmärtä̈̈-verbi. b-lauseet ovat väistymässä ja a-lauseet käymässä ainoiksi mahdollisiksi.

104. a Koira ymmärsi, että ruoka on valmista

b Koira ymmärsi ruoan valmiiksi.

105. a Etkö vihdoin ymmärrä, että seitikki on myrkyllinen?

b $"$ seitikkiä myrkylliseksi?

Luontevammilta tuntuvat sellaiset translatiivirakenteet, joissa subjektiosana on abstraktinen substantiivi tai jotka ovat määritelmän luonteisia

106. a Pariskunta ymmärsi avioeron välttämättömäksi.

b Lapsi ymmärtää tuolin huonekaluksi.

Selvin merkitysero rakenteiden välillä on verbin unohtaa objektina, kuten seuraavista esimerkeistä ilmennee.

107. a Puhuja unohti, että äännelait ovat poikkeuksettomia

b Puhuja unohti äännelait poikkeuksettomiksi.

108. a Lääkäri unohti, että hänen lempipotilaansa oli viimeinen.

b Lääkäri unohti lempipotilaansa viimeiseksi.

b-tapauksissa verbi unohtaa on implikatiivinen, ${ }^{10}$ unohtamisesta seuraa, että äännelait jäävät poikkeuksettomiksi ja potilas viimeiseksi. Että-lauseiden totuus taas on riippumaton unohta se edellyttää että-lauseen todeksi. Aivan rinnakkainen on suhde ettälauseen ja infinitiivirakenteen välillä:

109. a Unohdin, että kävin kaupassa.

b Unohdin käydä kaupassa.

Nämä esimerkit osoittavat mielestäni sen oletuksen mahdolliseksi, että infinitivi- ja translatiivirakenteet ovat "lausemaisuudeltaan" samanarvoiset. ${ }^{17}$

Viimeisenä tarkasteltavana ryhmänä ovat aistihavaintoa ilmai-

${ }^{10}$ Nimitystä on ensinnä ehdottanut Karttunen (1970).

"Lausenaisuren puattuminen voidaan todeta pronominitestillä. Seuraavas. âkseni lauseeseen Poliisi väitti...: sevat verbit näkee, kunlee, huomaa, tuntee. Näistä kaksi ensimmäistä eivät tunnu luontevasti saavan translatiivirakennetta. Väittäisin seuraavien esimerkkien b-lauseita nykykielessä käymättömiksi.

110. a Hän ei nähnyt, että mies oli sairas / kyömynenäinen. b * Hän ei nähnyt miestä sairaaksi / kyömynenäiseksi. 111. a Näitkö, että tie on jo valmis?

b * Näitkö tien jo valmiiksi?

112. a Kuulin, että naapurikylän asukkaat ovat pitkävihaisia.

b * Kuulin naapurikylän asukkaat pitkävihaisiksi.

113. a En huomannut, että hänen hameensa oli liian pitkä.

b * En huomannut hänen hamettaan liian pitkäksi.

Välitöntä aistihavaintoa ilmaisevat verbit, ellei niihin liity mitään lisävivahdetta, kuvaavat subjektipersoonan tahdosta riippumatonta, passiivista tapahtumaa, johon ei liity mitään päättelyä tai munta mutkikkaampaa aivotoimintaa. Sen sijaan lauseet $(117 \mathrm{a}-\mathrm{c}$ ) ilmaisevat, että havainnon yhteydessä on tehty subjektiivisia päätelmiä:

\section{4. a Vasemmisto katsoi ratkaisun huonoksi.}

b Tunnen sydämeni vahvaksi.

c Huomasin hänet järkeväksi ihmiseksi.

Tässä jaksossa olen käsitellyt verbejä, jotka saavat objektikseen olla-verbillisen rakenteen. Tarkastelin semanttisia eroja, joita on havaittavissa translatiivirakenteen ja toisaalta että-lauseen ynnä par. tisiippirakenteen välillä. Vaikka tilanne hieman vaihtelee ryhmä ryhmältä, yleisesti voidaan sanoa, että translatiivirakenne edellyttää suurempaa subjektiivisuutta, riippuvuutta subjektipersoonan tahdosta tai kuvittelusta, että-lause ja partisiippirakenne taas esittävät asian subjektipersoonan kokemulksesta riippumattomana. Jos pidämme kiinni siitä transformaatioteorian periaatteesta, että transformaatiot eivät vaikuta merkitykseen, joudumme tämän NOSTO-säännön tapauksessa ymmälle. Se tuntuu aiheuttavan merkityksen muuttumisen johtaessaan upotetun lauseen sulautumiseen. Toinen vaihtoehto olisi, että lopullinen pintarakennekin vaikuttaisi merkitykseen. 
Millä tavoin se tapahtuisi, sitä ei tämän päivän teoria pysty esittämään. ${ }^{28}$

3.3. NOSTO-säännön ala on rajoittunut nominaalilauseisiin suhteellisen hiljattain. Vanhan kirjasuomen esimerkit (Ojansuu 1909) osoittavat, että NOSTO subjektista objektiksi on ollut Agricolan aikaan tavallinen nykyistä partisiippirakennetta vastaavissa ilmauksissa:

115. a Ja eipe hen tachdo tiete / Minun sen olevan $\mathrm{b}$ hen neki heijet hädese soutauuan

e silloin esken homaitan se tauara ia Jumalan Lahia poisoleu

d Joca merkitze tuscat ia waijvat... io nyt Iopuuan

e leusin... Wartiat wlcona seisouan

$f$ ia cuuli heidhet ychten Campaleuan

Systeemi on ollut semanttisesti väljempi kuin nykysuomessa: esim. verbit merkitsee, katuu, itoitsee, löytää eivät enää saa partisiippirakennetta. Toisaalta tällöin ei ollut vielä tapahtunut partisiippi- ja translatiivirakenteiden tehtävien eriytymistä, sillä translatiivia esiintyy myös partisiipin päätteenä:

116. a Autuaxi he lausuuat sen Canssan

b eij muistetan ensingen ollehexi

e leusi temen Christusen iuri ilman syndi syndynyxi ja elauan

Viimeinen esimerkki, jossa rakenteet ovat jopa rinnasteisina, osoittaa parhaiten tilanteen selkiytymättömyyden. — Tämän jälkeen oletetaan tapahtuneen nostetun objektin uudelleen tulkitseminen genetiiviksi. Tämä tapahtui vain niissä tapauksissa, joissa ei ollut translativia. Muutoksen yhtenä taustatekijänä voi spekuloida olleen sen, että ilman genetiivist
kolmekin samaa muotoa:

117. Miehet uskoivat koirat näkevän linnut.

Muotojen samanlaisuus estää partisiippia toimimasta juuri siinä tehtävässä, mihin se käy, toisin kuin että-lause. Sanajärjestystä ei käy muuttaminen ilman sekaannuksen vaaraa. Kysymyslauseista esimerkiksi tulee epäselviä

${ }_{18}$ Kolmas ja todennäköisin ratkaisu on esittää semanttiset erot syvärakenteessa: vain esimerkin (82) tapauksessa olisi kyse parafraaseista.
117. b Mitkä miehet uskoivat näkevän linnut? c Mitkä miehet uskoivat koirat näkevän?

Reinterpretaatiota on luultavasti tukenut syntaktisen joustavuuden tarve. Mutta sen jälkeen kun partisiippirakenteen subjekti oli tulkittu genetiiviksi, sen ei enää voinutkaan katsoa kuuluvan hallit sevan verbin rektioon. Mikään partisiippirakenteen osista ei siirry toisen lauseen jäsenelssi. Muodostuu finiittilauseen ja sulautuneen rakenteen välimuoto, partisippirakenne. Etta-lauseesta se eroa sanajärjestyksen joustavuuden suhteen; siitä puuttuu myös kongruenssi sekä mahdollisuus käyttää modusta. Sulautunein tyyppi infinitiivi- ja translatiivirakenne eroaa kahdesta muusta sikäli, etta siltä puuttuu tempus ja lauseadverbiaalit. Kun partisiippi- ja translatiivirakenteet ovat erottuneet toisistaan morfologisesti, semanttinen eriytyminen on voinut alkaa.

\section{KIRJALLISUUTTA}

Borkin, Ann (1973): To be and not to be. Papers from the 9th Regional Meeting of the Chicago Linguistic Society.

(nds, Joseph (1972): A reformulation of certain syntactic transformations S. Peters (toin) CArfs.
Clifs. Hakulinen, Auli \& Lauri Karttunen (1973): Missing Persons: On Generic
Sentences in Finnish. Papers from the 9th Regional Meeting of the Chicago Linguistic Society.

Hakulinen, Lauri (1968): Suomen kielen ralrenne ja kehitys. Otava, Helsink Ikola, Osmo (1971): Lauseenvastikkeista ja upotetuista lauseista. Sananjalke,

" (1973): Subjekti vai predikativiv Eräs lauseenjäsennyksen umpikuja.

Karttunen, Lauri (1970): Implicative Verbs. Language 46:4.
Kiparsky, Paul \& Carol (1970): Fact. Bierwisch - Heidolph (toim.) Recent Advanoes in Linguistics. Mouton \& Co. Haag.

Luomi, Lea (1972): Henklotekijâiset yksipersoonaiset îmaulset helsinkiliäiste pappien saarnakielessä. Pro gradu -tutkielma, Helsingin yliopiston suome kielen laitos.

(1968) : Introduction to theoretical linguistics. Cambridge University Press.

): Mikael Agricolan kielestä. SKS, Helsinki. 
Postal, Paul M. (1972) : On Raising. Tlmestyy The M.I.T. Pressin kustantamana. Sankkonen, Pauli (1965): Itâmerensus kenteiden historian I, SKS, Helsink.

(1966) : 1. inimithvin latiivin lauseopillinen jäsentyminen. Virittajä.

Wiik, Kalevi (1972): Suomen akkasatinvobjektin muoto. Turun yliopiston fone-

v. Wrivers.

AULI HAKULINEN: Semantic observations on complement clauses In this paper, three aspects of complementation are considered.

1. It has been suggested by Postal that Raising is a universal rule; i.e. it is a rule needed in the grammar of any natural language. EQUI and RAISING, then, would together account for the derivation of infinite complements. In the first section of the paper it is shown that subject os bes laising is indeed a necessary rule in the gen taitaa olla oin ths ande - Some problems are cous bodal verbs like voi 'ean' and tïytyy'must'. The fact that modals have both a root and an epistemic reading camnot be captured revealingly by a generative semantic description of their deep structure. Secondly, it seems that the rule Subject-to-Subject Raising has to include cases like Asian taytyy ratketa, that is, the denitive must be viewed

as one possible subject ease.
3. The rule Subject-to-Object Raising is one of the more questionabie proposals made by postal; it is not accepted unhesitatingly even for english. Raising was still common in Finnish four centuries ago, e.g. in sentences like lousin... Wartiat wlcona seisoun and Autuaxi he lausunut sen Canssan. When, in eases like the former, the Accusative (Wartiat) was later replaced by genitive as a result of a re-analysis, it could no longer be seen as a constituent of the matrix clause on the surface, any more than the othor parts of the complement clause. It remained a Genitive sabject of the participial clause Ratising was then rest about between a thotclanse and its be-less equivalent, illustrated by example like Ajattelin, että mummo on vïmeinen kamassi vs. Ajattelin mummoa vir meisetssi loamassitksi. 